Reprod. Nutr. Dévelop., 1984, 24 (2), 107-116.

\title{
The effect of short and skeleton long photoperiods on the plasma concentrations of prolactin and cortisol in sheep
}

\author{
B. R. BRINKLOW, J. M. FORBES (1)
}

Department of Animal Physiology and Nutrition

University of Leeds, Leeds, LS2 9JT, U. K.

\section{Summary}

Suffolk-cross lambs, aged eight weeks, were exposed to either short photoperiods (8L: 16D, SP ; 7 castrated males and 6 females) or skeleton long photoperiods (7L : 10D : 1L : 6D, SLP ; 6 castrated males and 7 females). They were fed individually on a complete pelleted diet at $70 \mathrm{~g} / \mathrm{kg}$ live weight $0.75 /$ day. Blood samples were taken monthly by jugular puncture for three months and, after 39 days on experiment, jugular catheters were inserted for frequent sampling over a $24 \mathrm{~h}$ period. The samples were assayed for prolactin using radioimmunoassay and for cortisol by competitive protein binding.

SLP caused a large and significant increase in plasma prolactin throughout the experiment, with no effect of sex. During the $24 \mathrm{~h}$ period there were consistent peaks of prolactin at the start of both dark phases under SLP, with lower levels around the start of both light phases ; under SP, prolactin tended to be higher in the middle of the light phase and the midde of the dark phase than at other times.

Considerable hourly fluctuations were observed in cortisol levels but an obvious $24 \mathrm{~h}$ rhythm was not. Mean levels were, however, significantly higher under SP $(38.3 \mathrm{nmol} / \mathrm{l})$ than under SLP $(26.8 \mathrm{nmol} / \mathrm{l})$.

\section{Introduction.}

Photoperiod has been shown to influence the seasonal reproductive cycles of many Spring/Summer - (Reiter, 1980) and Autumn/Winter - (see Lincoln and Short, 1980) breeding animals. It has also been shown to influence growth of both cattle (Peters et al., 1978) and sheep (Forbes et al., 1979 ; Schanbacher and Crouse, 1980) though not in every case (cattle, Roche and Boland, 1980 ; sheep, Hackett and Hillers, 1979).

The mechanisms involved in this effect on growth have not been elucidated although a role for prolactin has been suggested because long photoperiod elevates both growth and prolactin (see Forbes, 1982) and intravenous infusion of

(1) Correspondence to Dr. J. M. Forbes at the above address. 
prolactin into sheep, kept in the dark to mimic the plasma levels found under long photoperiods, stimulates nitrogen retention (Brinklow and Forbes, 1982). Plasma levels of cortisol have been shown to be negatively correlated with growth in cattle (Purchas et al., 1971 ; Obst, 1974 ; Trenkle and Topel, 1978) and in one report (Leining, Tucker and Kesner, 1980) prepubertal bulls were shown to have reduced levels of cortisol under $16 \mathrm{~h}$ compared with $8 \mathrm{~h}$ photoperiods. Treatment with exogenous corticosteroids depresses growth and it is generally considered that these hormones are catabolic (see Thomas and Rodway, 1983).

It has been shown by Ravault and Ortavant (1977) that a nocturnal "flash » of light can stimulate prolactin secretion and the aim of the present study was to investigate the effect of short (8L: 16D) and skeleton long (7L: 10D : 1L: 6D) photoperiods, which have been shown to have differential effects on growth (Brinklow et al., 1984 ; Schanbacher and Crouse, 1981), on the plasma levels and $24 \mathrm{~h}$ profiles of prolactin and cortisol in parellel with the effects on growth and carcass measurements which are reported elsewhere (Brinklow et al., 1984). Level of feeding was controlled to avoid confounding any effects of photoperiod on hormone secretion by the likely effects on voluntary intake caused by the photoperiod treatments (Forbes et al., 1979; Schanbacher and Crouse, 1981).

\section{Methods.}

Animals and management. -26 Suffolk $\times$ Greyface lambs, born in March, were reared by their mothers under natural photoperiods at a latitude of $53 \mathrm{~N}$ until being weaned on 5 May and one week later moved into individual pens in a lightproof building with a 12L : 12D lighting pattern. From 22 May until mid-August the animals in one room (seven castrated males and six females) were exposed to short photoperiod (8L : 16D) while those in another room of the same size (six castrated males and seven females) were exposed to skeleton long photoperiod (7L: 10D : 1L : 6D). They were fed at a restricted level of $70 \mathrm{~g} / \mathrm{kg}$ live weight $0.75 /$ day on a complete pelletted diet $1500 \mathrm{~g}$ rolled barley $/ \mathrm{kg} ; 490 \mathrm{~g}$ dried grass $/ \mathrm{kg} ; 10 \mathrm{~g}$ mineral and vitamin mix $/ \mathrm{kg}:-176 \mathrm{~g}$ crude protein $/ \mathrm{kg} D M ; 46 \mathrm{~g}$ crude fibre/kg DM ; $12.8 \mathrm{MJ}$ estimated $\mathrm{ME} / \mathrm{kg} \mathrm{DM}$ ) given at $0800 \mathrm{~h}$ each day; water was available at all times. Environmental temperature was not controlled, neither were records kept of the temperature in the building. Blood samples were taken by jugular puncture at approximately monthly intervals. On the morning of 29 June jugular catheters were placed in three animals of each sex in each treatment and blood samples were taken every $20 \mathrm{~min}$ from $1200 \mathrm{~h}$ for $24 \mathrm{~h}$. During the hours of darkness a dim light with a narrow beam, attached to the operator's headband, was used to facilitate sample collection with minimal exposure of the sheep' eyes.

Details of live weight gains and slaughter parameters are given in the paper of Brinklow et al. (1984).

Hormone assays. - All plasma samples were assayed for prolactin using a double-antibody equilibrium method with an anti-ovine-prolactin raised in rabbits (R441BS) and kindly donated by Dr. J. M. Chesworth, School of Agriculture, Aberdeen. Full details of the assay methodology are given by Brinklow (1983). 
There was no cross-reaction with ovine $\mathrm{LH}, \mathrm{FSH}$ or TSH up to concentrations of 10000,10000 and $8000 \mathrm{ng} / \mathrm{ml}$, respectively, while growth hormone cross-reacted at concentrations of over $1000 \mathrm{ng} / \mathrm{ml}$, a level never encountered under physiological conditions. The inter-assay variance for 10 assays for plasma containing $57 \mathrm{ng} / \mathrm{ml}$ of prolactin was $4.6 \%$, while intra-assay variance was $5.6 \%$. The mean lower detection limit was $7 \mathrm{ng} / \mathrm{ml}$.

Plasma from the $24 \mathrm{~h}$ collection of blood from four animals under each photoperiod was assayed for cortisol.

The method was based on the competitive protein binding method of Murphy (1967) using corticosteroid binding protein from pooled human plasma, as described briefly by Thomas and Rodway (1983) and in detail by Brinklow (1983). The mean recovery of cortisol from the extraction procedure was $98.1 \pm 6.1 \%$. Corticosterone cross-reacted $(90 \%)$ but levels in sheep plasma are usually less than $3 \mathrm{nmol} / \mathrm{l}$ (Ferguson and Cox, 1975); progesterone crossreacted to a lesser extent $(25 \%)$ but levels in males and prepubertal sheep are less than $2 \mathrm{nmol} / /$ (Ferguson and Cox, 1975) ; testosterone showed $6.5 \%$ crossreactivity, but as the animals in this experiment were castrated males or females endogenous levels would be very low. The inter-assay variance for six assays for a plasma sample containing $116 \mathrm{nmol} / \mathrm{l}$ of cortisol was $15.3 \%$ while intra-assay variance was $8.7 \%$; the detection limit was $0.28 \mathrm{pmol} /$ tube.

Statistical analysis. - All hormone levels were subjected to logarithmic transformation before parametric analysis to equalise the variance between low and high values. Analysis of variance was used (Nie et al., 1975) for comparisons between photoperiods and sexes.

To detect consistent fluctuations within $24 \mathrm{~h}$ profiles a non-parametric sign test was employed (Snedecor and Cochran, 1980), as used for comparable data by Lincoln et al. (1982). Individual values were assigned as being above, equal to or below the median value for the hormone during the whole sampling period for that animal. The times at which at least five of the six animals under each treatment had values above or below the median were determined and a series of at least two consecutive high or low values was taken to be a consistent peak or trough, respectively.

Cortisol shows marked, frequent peaks and secretory spikes were defined using criteria similar to those described by Fulkerson and Tang (1979) for ovine cortisol secretion, that is when the plasma concentration in a sample was as least $10 \mathrm{nmol} / \mathrm{I}$ higher than that of the previous sample and the following sample also showed a level which was above the initial one. The end of an episode was when the concentration fell to at least as low as the pre-peak level in two consecutive samples.

\section{Results.}

Plasma levels of prolactin were considerably higher under the skeleton long photoperiod than the short photoperiod at all times of day or night (table 1 and fig. 1). The means values for the $24 \mathrm{~h}$ profiles were very highly significantly different $(P<0.001)$. 
TABLE 1

Effect of photoperiod on plasma prolactin concentrations in samples taken by jugular puncture $(\mathrm{ng} / \mathrm{ml})$.

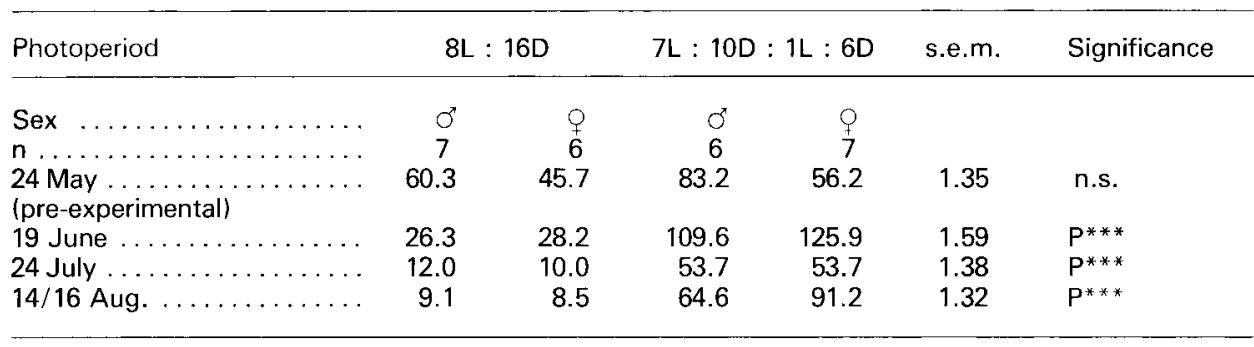

s.e.m., standard error of a treatment mean ; $\mathrm{P}^{* * *}$, effect of photoperiod significant at $\mathrm{P}<0.001$.

No differences were evident in plasma concentrations of prolactin due to sex in either skeleton long or short photoperiods, though the castrated males had increased levels $(P=0.056)$ in the first venepuncture sample taken at the end of the pre-experimental period under 12L : 12D. Table 1 shows a highly significant difference between the plasma prolactin levels in both sexes due to photoperiod treatment, there being increased levels under skeleton long photoperiods in all cases.

Figure 1 shows the mean $24 \mathrm{~h}$ profiles of plasma prolactin for six animals from each photoperiod treatment on 30-31 June.

Mean levels fluctuated considerably several times each day and high or low levels were synchronised in the animals, as indicated by the arrow-heads in figure 1. Consistent decreases appeared around "dawn " and increases in the middle of the dark phase ; the amplitude of these changes was greater in the group exposed to skeleton long photoperiod. Prolactin appeared to decrease during the $1 \mathrm{~h}$ pulse of light and increase at "dusk " although this was not as obvious in those animals kept in short days.

Cortisol. - The mean $24 \mathrm{~h}$ profiles of plasma cortisol for six sheep from each photoperiod treatment are shown in figure 2 . There were considerable fluctuations which make it impossible to distinguish any consistent rhythm.

The mean cortisol levels for all of the samples taken during $24 \mathrm{~h}$, for castrated males and females respectively, were $34.4 \pm 14.2$ and $42.1 \pm 6.5 \mathrm{nmoles} / \mathrm{l}$ for skeleton long photoperiod and $25.4 \pm 3.8$ and $28.1 \pm 4.2$ for short photoperiod. Photoperiod effects were significant $(P<0.05)$ but those of sex were not.

The number of secretory spikes, as defined in the Methods section, was $12.4 \pm 0.4(n=6)$ and $12.0 \pm 1.2(n=6)$ for skeleton long and short photoperiods, respectively, and did not differ significantly. The difference in mean plasma cortisol levels due to treatment was thus due to differences in peak height rather than differences in number of peaks. 


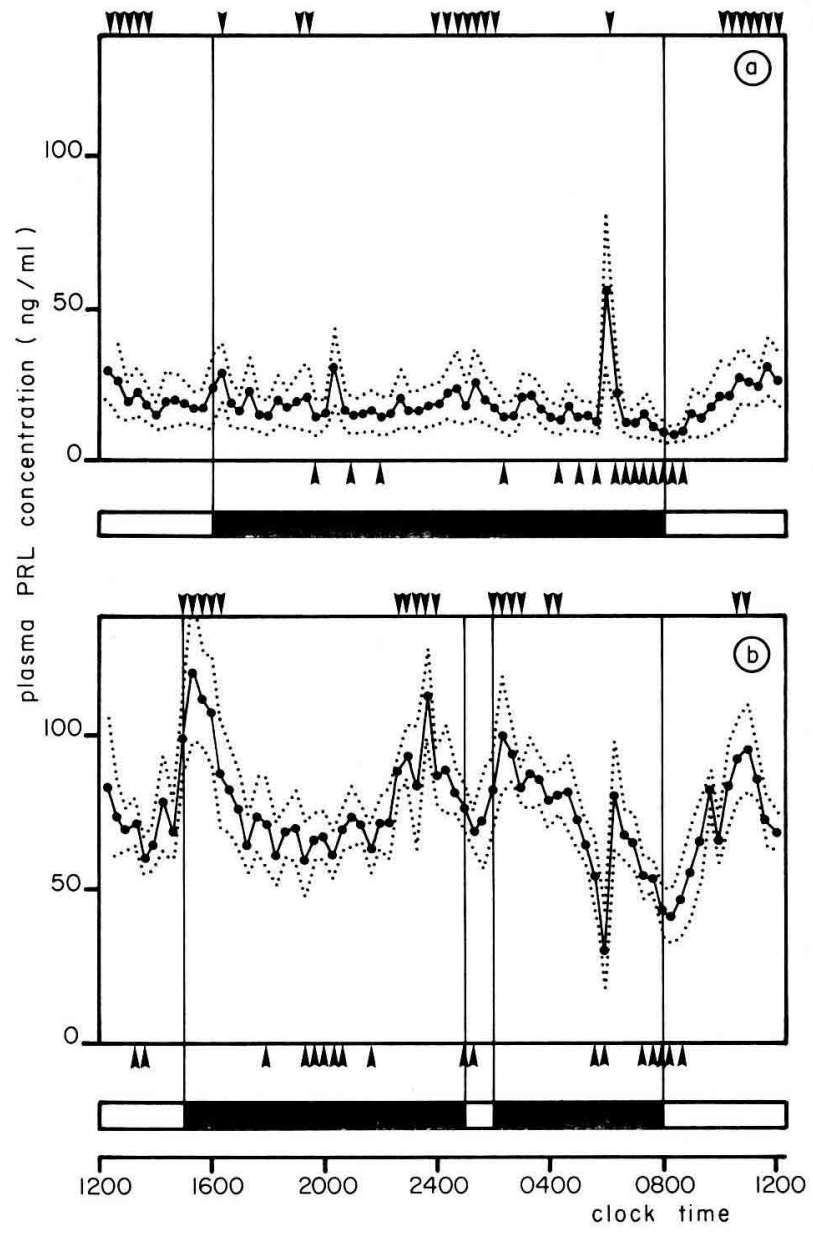

FIG. 1. $-24 \mathrm{~h}$ profiles of plasma prolactin under a) short and b) skeleton long photoperiods. Each point is the mean for six animals and the dashed lines show one standard error from the mean. The arrowheads indicate times at which values for at least five out of the six were above ( $\mathbf{V})$ or below (A) the $24 \mathrm{~h}$ median for each individual. The horizontal bar beneath each graph shows the daily cycle of light with the solid part indicating the scotophase.

The only correlation between a hormone and a growth parameter was that between carcass length $(\mathrm{CL}, \mathrm{mm})$ and the mean of the $24 \mathrm{~h}$ cortisol levels $(\mathrm{C}$, nmoles/I) :

$$
C L=758-104( \pm 44) \log 10 \mathrm{C} \quad(r=-0.62 ; P<0.05) .
$$

\section{Discussion.}

The results of this experiment confirm those of Ravault and Ortavant (1977) and Schanbacher and Crouse (1981) that the photoperiodic control of prolactin secretion is consistent with a concidence model (Bunning, 1964), with skeleton 

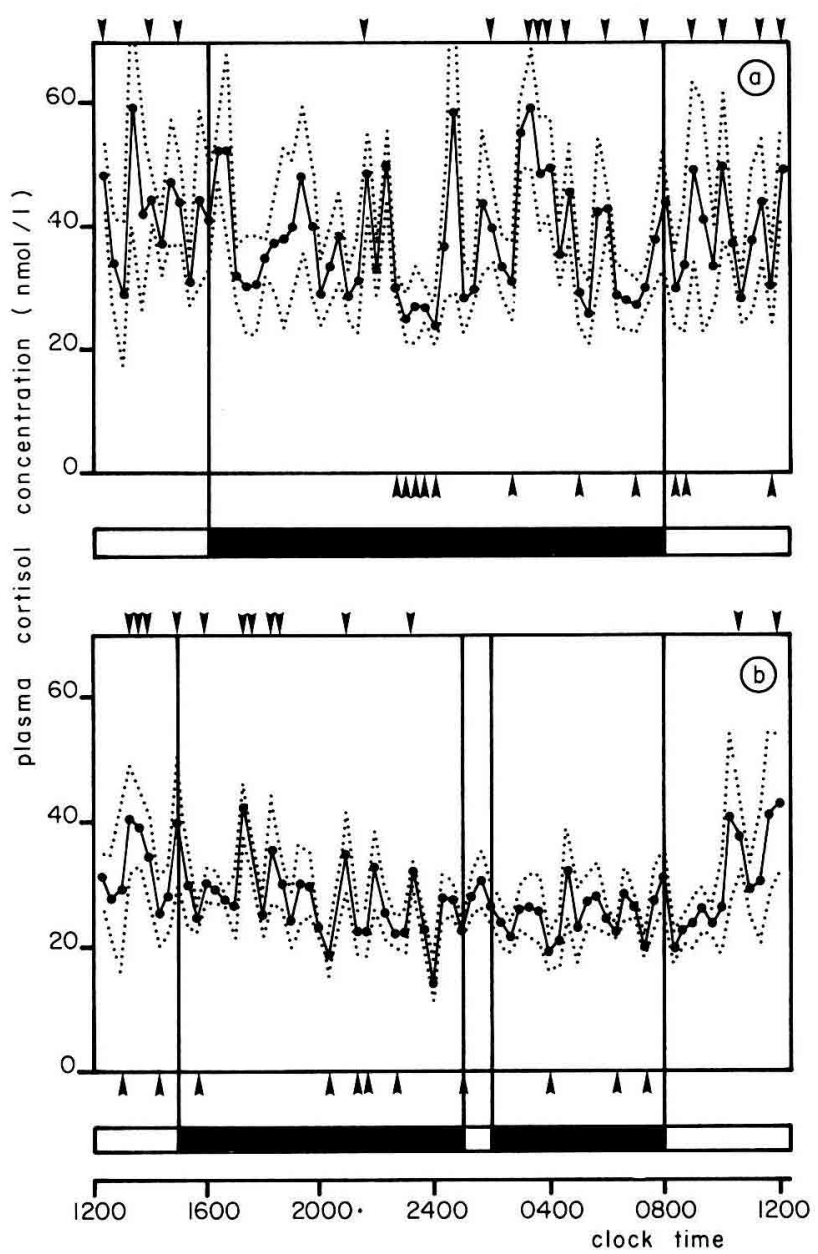

FIG. 2. - $24 \mathrm{~h}$ profiles of plasma cortisol under a) short and b) skeleton long photoperiods. Each point is the mean for six animals and the dashed lines show one standard error from the mean. The arrowheads indicate times at which values for at least five of the six animals were above ( $\boldsymbol{\nabla}$ ) or below (A) the $24 \mathrm{~h}$ median for each individual. The horizontal bar below each graph shows the daily cycle of light with the solid part indicating the scotophase.

long photoperiods of $7 \mathrm{~L}: 9 \mathrm{D}: 1 \mathrm{~L}: 7 \mathrm{D}$ and $7 \mathrm{~L}: 10 \mathrm{D}: 1 \mathrm{~L}: 6 \mathrm{D}$ having similar effects to long photoperiods in increasing the plasma levels of prolactin. Although prolactin tended to fall as the experiment progressed the relative difference was maintained and there was no evidence that the animals were becoming refractory to the skeleton long photoperiod towards the end of the experiment (table 1), as suggested by the results of Ravault and Ortavant (1977). Neither can the fall be explained by temperature as there was no consistent decline in environmental temperature during the experiment, which ran from late May until mid-August. 
Though Wilson and Lapwood (1978) were unable to detect a daily rhythm in circulating prolactin in sheep under natural photoperiods, artificial photoperiods have given rise to a number of reports of a rhythm of prolactin secretion, including the present experiment. Using skeleton long photoperiods of 7L : 5D : 1L : 7D Ravault and Ortavant (1977) found evidence of a peak around the end of both light phases, with a fall at the start of the $1 \mathrm{~h}$ light pulse. We found a similar pattern, though the low levels throughout the duration of the $7 \mathrm{~h}$ light phase found by Ravault and Ortavant (1977) were not evident here. Brown and Forbes (1980) found that the most salient feature of the daily prolactin rhythm in sheep under photoperiods of 8,12 and $16 \mathrm{~h}$ was a peak in the early dark phase beginning just prior to the change from light to darkness. A similar feature was also noted by Ravault and Ortavant (1977) with 8 and $16 \mathrm{~h}$ photoperiods and by Barrell and Lapwood (1978) with a $14.5 \mathrm{~h}$ photoperiod. This peak associated with the end of the photoperiod was found in the skeleton long photoperiod group but was far less obvious in the short photoperiod group in the present study. We have seen consistently decreased prolactin levels around the beginning of the photoperiod in both groups which has only previously been seen when samples were taken, as in this experiment, at 20 min intervals (Barrell and Lapwood, 1978). It is clear that, however consistent prolactin profiles might be within an experiment, variation among experiments is considerable. Although effects of skeleton long photoperiod on prolactin secretion are well documented, we felt that it was important to confirm that it occurred under the conditions of our experiments in order to be sure that we had a biological response to the photoperiod treatments.

Reports are sparse regarding photoperiod and the secretion of corticosteroids. In prepubertal bulls Leining et al. (1980) found that concentrations of cortisol in single samples taken by venepuncture at the midpoint of the light phase were higher under $8 \mathrm{~h}$ than under 16 or $20 \mathrm{~h}$ photoperiods. In view of the extremely pulsatile nature of cortisol secretion this finding must be viewed with caútion, however; Peters et al. (1980) found no effect of photoperiod on the plasma cortisol levels in heifers when the samples were taken four times during the day. The only experiment in which cortisol has been measured in sheep under different photoperiods similar to those in this experiment was that of Lincoln et al. (1982); they found no difference between mean levels from frequent sampling of mature sheep for $24 \mathrm{~h}$ under $8 \mathrm{~L}: 16 \mathrm{D}$ or $16 \mathrm{~L}: 8 \mathrm{D}$. Perhaps there is a special effect of skeleton long photoperiod on the pituitary-adrenal axis or perhaps young animals are more susceptible; the only other report of a photoperiodic effect on plasma cortisol (Leining et al., 1980) was with young animals. The effect of photoperiod on plasma cortisol concentrations demonstrated in this experiment shows that skeleton long photoperiod is effective in sheep as is long photoperiod in cattle.

The pattern of cortisol spikes showed that the main difference between the two photoperiods was in the size of the peaks rather than in their frequency. The mean number of episodes compares closely with that observed by Fulkerson and Tang (1979) in adult Merino ewes. However, Kennaway et al. (1981), using a skewness coefficient test to produce inlier and outlier subgroups, showed less 
frequent peaks ; the methods of analysis are arbitrary and it is difficult to compare results when different methods have been used ; there have also been differences in the assay methodology used, ours being relatively non-specific. The fact that mean cortisol levels from several animals show evidence of peaks indicates that there is some degree of synchronisation between animals; however, the stimuli which might syncronise cortisol secretion are unknown.

Although prolactin infusion into growing lambs stimulates nitrogen retention (Brinklow and Forbes, 1982) and active immunisation against prolactin depresses growth (Ohison et al., 1981) there has been a report of a photoperiodic effect on growth in cattle in which prolactin was very low due to low environmental temperatures (Peters et al., 1980). It seems unlikely, therefore, that prolactin alone is responsible for the increased growth in long or skeleton long photoperiods. Perhaps cortisol secretion, which the results of this experiment show to be depressed by skeleton long photoperiod, also plays a part in the photoperiodic effects on growth. The long-term treatment of sheep with cortisol caused fat deposition with muscle resorption (Spurlock and Glegg, 1962). In an experiment subsequent to the one reported here (Brinklow, 1983) short photoperiod again gave higher cortisol levels than skeleton long photoperiods, but this was blocked by pinealectomy ( $P<0.05$ for interaction) as was the effect on weight gain. Thus, circumstantial evidence suggests that cortisol may be involved in mediating the effects of daylength on growth in sheep.

In trying to explain how photoperiod affects growth we should consider the changes in prolactin, cortisol, melatonin (Rollag and Niswender, 1976) and any other hormones that are found to change in response to lighting pattern, rather than assuming that the whole effect can be attributed to any single hormone.

Reçu en juin 1983.

Accepté en novembre 1983.

Acknowledgements. - The authors are most grateful to Mr. R. Jones for the management of the animals, to the Division of Steroid Endocrinology. University of Leeds for advice and assistance with the cortisol assay and to Dr. R. G. Rodway for his help and encouragement. The work was supported by a grant from the Agricultural Research Council.

Résumé. Effet de photopériodes fractionnées courtes et longues sur les concentrations plasmatiques de la prolactine et du cortisol chez la Brebis.

Des agneaux croisé Suffolk âgés de 8 semaines ( 7 mâles castrés et 6 femelles) ont été exposés à de courtes périodes de lumière $(8 \mathrm{~L}: 16 \mathrm{D} ; \mathrm{SP})$ ou à de longues photopériodes fractionnées (7L: 10D : 1L: 6D; SLP) $(6$ mâles castrés et 7 femelles). Ces animaux recevaient un régime composé exclusivement de pellets à raison de $70 \mathrm{~g}$ par $\mathrm{kg}$ de poids $\mathrm{vif}^{0,75}$ par jour. Des prises de sang ont été effectuées chaque mois par ponction de la jugulaire et, après 39 jours d'expérimentation, des cathéters ont été mis en place afin de pratiquer des prélèvements fréquents pendant une période de 24 heures. La prolactine a été dosée par radioimmunoessai et le cortisol par compétition de liaison à une protéine. 
Dans le schéma "SLP » on a constaté une augmentation significative de la prolactine plasmatique tout au long de l'expérimentation, sans noter d'influence du sexe. Au cours d'une période de $24 \mathrm{~h}$ on a toujours observé des maxima de prolactine au début des deux phases d'obscurité et des niveaux moins élevés au début des phases claires. Dans le schéma "SP » la prolactine avait tendance à atteindre un niveau plus élevé au milieu de la phase lumineuse et au milieu de la phase obscure.

Pendant la période de $24 \mathrm{~h}$ les niveaux de cortisol ont montré des variations notables, mais sans rythme caractérisé. Les niveaux moyens, cependant, étaient nettement plus élevés dans le schéma "SP " $(38,3 \mathrm{nmol} / \mathrm{I})$ que dans le schéma " $\operatorname{SLP}$ » $(26,8 \mathrm{nmol} / \mathrm{I})$.

\section{References}

BARRELL G. K., LAPWOOD K. R., 1978. Effects of pinealectomy of rams on secretory profiles of luteinising hormone, testosterone, prolactin and cortisol. Neuroendocrinology, 27, 216-227.

BRINKLOW B. R., 1983. The effect of photoperiod on the growth of lambs. Involvement of hormones and the pineal organ. Ph. thesis, Univ. Leeds, p. 377.

BRINKLOW B. R., FORBES J. M., 1982. Prolactin infusion causes increases nitrogen retention in lambs in continuous darkness. Proc. Nutr. Soc., 42, 38A.

BRINKLOW B. R., JONES R., FORBES J. M., 1984. The effect of daylength on the growth of lambs. 5. Skeleton long photoperiod. Anim. Prod. (Accepted for publication).

BROWN W. B., FORBES J. M., 1980. Diural variations of plasma prolactin in growing sheep under two lighting regimes and the effect of pinealectomy. J. Endocr., 84, 91-99.

BUNNING E., 1964, The physiological clock. Springer Verlag, Berlin.

FERGUSON K. A., COX R. I., 1975. Hormones, 101-116. In M. H. BLUNT, The blood of sheep, Springer Verlag, Berlin.

FORBES J. M., 1982, Effects of lighting pattern on growth, lactation and food intake of sheep, cattle and deer. Livest. Prod. Sci., 9, 361-374.

FORBES J. M., EL SHAHAT A. A., JONES R., DUNCAN J. G. S., BOAZ T. G., 1979. The effect of daylength on the growth of lambs. 1. Comparison of sex, level of feeding, shearing and breed of sire. Anim. Prod., 29, 33-42.

FULKERSON W. J., TANG B. Y., 1979. Ultradian and circadian rhythms in the plasma concentration of cortisol in sheep. J. Endocr., 81, 135-141.

HACKETT M. R., HILLERS J. K., 1979: Effect of artificial lighting on feeder lamb performance. J. anim. Sci., 49, 1-4.

KENNAWAY D. J., OBST J. M., DUNSTAN E. A., FRIESEN H. G., 1981. Ultradian and seasonal rhythms in plasma gonadotropins, prolactin, cortisol and testosterone in pinealectomised rams. Endocrinology, 108, 639-646.

LEINING K. B., TUCKER H. A., KESNER J. S., 1980. Growth hormone, glucocorticoid and thyroxine response to duration, intensity and wavelength of light in prepubertal bulls. $J$. anim. Sci., 51, 932-942.

LINCOLN G. A., SHORT R. V., 1980. Seasonal breeding: Nature's contraceptive. Recent Progr. Horm. Res., 36, 1-52.

LINCOLN G. A., ALMEIDA D. F. X., KLANDORF H., CUNNINGHAM R. A., 1982. Hourly fluctuations in the blood levels of melatonin, prolactin, luteinising hormone, follicle stimulating hormone, testosterone, tri-iodothyronine and cortisol in rams under artificial photoperiods and the effects of cranial sympathectomy. J. Endocr., 92, 237-250.

MURPHY B. E. P., 1967. Some studies of the protein-binding of steroids and their application to the routine micro and ultramicro measurement of various steroids in body fluids by competitive protein binding radioassay. J. clin. Endocr. Metab., 27, 973-990.

NIE N. H., HULL C. H., JENKINS J. G., STEINBRENNER K., BENT D. A., 1975. Statistics package for the social sciences, McGraw Hill, New York.

OBST J. M., 1974. The relationship between plasma corticoid and growth rate in cattle. Proc. aust. Soc. anim. Prod., 10, 41-44. 
OHLSON D. L., SPICER L. J., DAVIS S. L., 1981. Use of active immunisation against prolactin to study the influence of prolactin on growth and reproduction in the ram. J. anim. Sci., 52, 1350-1359.

PETERS R. R., CHAPIN L. T., LEINING K. B., TUCKER H. A., 1978. Suplemental lighting stimulates growth and lactation in cattle. Science, 199, 911-912.

PETERS R. R., CHAPIN L. T., EMERY R. S., TUCKER H. A., 1980. Growth and hormonal response of heifers to various photoperiods. J. anim. Sci, 51, 1148-1153.

PURCHAS R. W., PEARSON A. M., HAFS H. D., TUCKER H. A., 1971. Some endocrine influences on the growth and carcass quality of Holstein heifers. J. anim. Sci., 33, 836-842.

RAVAULT J. P., ORTAVANT R., 1977. Light control of prolactin in sheep. Evidence for a photoinducible phase during diurnal rhythm. Ann. Biol. anim. Bioch. Biophys., 17, 459-473.

REITER R. J., 1980. The pineal and its hormones in the control of reproduction. Endocr. Rev., 1. 109-131.

ROCHE J. F., BOLAND M. P., 1980. Effect of extended photoperiod in winter on growth rate of Freisian male cattle. Ir. J. agric. Res., 19, 85-90.

ROLLAG M. D., NISWENDER G. D., 1976. Radioimmunoassay of serum concentrations of melatonin in sheep exposed to different lighting regimes. Endocrinology, 98, 482-489.

SCHANBACHER B. D., CROUSE J. D., 1980. Growth and performance of growing-finishing lambs exposed to long and short photoperiods. J. anim. Sci., 51, 943-948.

SCHANBACHER B. D., CROUSE J. D., 1981. Photoperiodic regulation of growth. A photosensitive phase during the light dark cycle. Amer. J. Physiol., 241, E1-E5.

SNEDECOR G. W., COCHRAN W. G., 1980. Statistical methods. lowa State University Press, Ames.

SPURLOCK G. M., CLEGG M. T., 1962. Effect of cortisone acetate on carcass composition and wool characteristics of weaned lambs. J. anim. Sci., 21, 494.

THOMAS K. M., RODWAY R. G., 1983. Effects of trenbolone acetate on adrenal function and hepatic enzyme activities in female rats. J. Endocr., 98, 121-127.

TRENKLE A., TOPEL D. G., 1978, Relationships of some endocrine measurements to growth and carcass composition of cattle. J. anim. Sci., 46, 1604-1609.

WILSON P. R., LAPWOOD K. R., 1978. Studies of hormone secretion in Romney rams : luteinising hormone, testosterone and prolactin profiles, $\mathrm{LH} /$ testosterone interrelationships and the influence of seasons. Theriogenology, 9, 279-294. 